\title{
Age and lactation specific disposal pattern in Sahiwal cattle and influence of various genetic and non-genetic factors
}

\author{
A. Upadhyay ${ }^{1}$, D. K. Sadana ${ }^{2}$, A. K. Gupta ${ }^{1}$, A. K. Chakravarty ${ }^{1}$, S. Dash ${ }^{1}$, M. K. Das ${ }^{1}$, Anushree M. ${ }^{1}$ and P. R. Shivahre ${ }^{1}$
}

1. Dairy Cattle Breeding Division, National Dairy Research Institute, Karnal, Haryana, India;

2. National Bureau of Animal Genetic Resources, Karnal, Haryana, India.

Corresponding author: A. Upadhyay, e-mail: upadhyay.arpan@gmail.com,

DKS: sadana.dk@gmail.com, AKG: guptaak2009@gmail.com, AKC: ak_chakravarty@yahoo.co.in,

SD: dr.soumya10@gmail.com, MKD: das.manasvet2011@gmail.com,

AM: anushree.meshram88@gmail.com, PRS: drpr06@gmail.com

Received: 27-06-2014, Revised: 10-09-2014, Accepted: 14-09-2014, Published online: 19-10-2014

doi: 10.14202/vetworld.2014.842-847. How to cite this article: Upadhyay A, Sadana DK, Gupta AK, Chakravarty AK, Dash S, Das MK, Anushree M, Shivahre PR (2014) Age and lactation specific disposal pattern in Sahiwal cattle and influence of various genetic and non-genetic factors, Veterinary World 7(10): 842-847.

\begin{abstract}
Premature disposal of female calves before reaching milch herd and undesirable disposal of lactating cows are the major constraints in achieving larger herd size. During the early lactations, younger cows are supposed to give higher milk yield and undesirable disposal of early calvers, thereby, greatly hampers profitability of a dairy farm. Knowledge of the incidence of disposal along with reasons in various age groups and at various parities is essential to identify which age group or parity is more vulnerable for disposal. Moreover, knowledge of various genetic and non-genetic factors associated with disposal of animals may also be helpful in developing breeding and management strategies to reduce the incidence of disposal. In most of the studies, it was found that major reasons of disposal of dairy cattle were mortality among female calves and involuntary culling among adult lactating cows. Maximum mortality in female calves was observed during earlier ages and pneumonia, gastro-enteritis and debility were major reasons of female calf mortality. Whereas, most of the adult cows left the herd, due to teat and udder and reproductive problems. Moreover, indigenous breeds were found to be more adapted to Indian tropical climatic conditions in comparison to crossbred and exotic cattle breeds.
\end{abstract}

Keywords: culling, disposal pattern, heritability estimates, mortality, Sahiwal cattle.

\section{Introduction}

Sahiwal is known as best milch breed of zebu cattle and also known for its endurance, resistance to tropical diseases, tick resistance and drought resistance. Due to these attributes, Sahiwal is one of the few indigenous breeds which has been imported by many other countries from India/Pakistan and has been used either for crossing or later on for incorporating some zebu genes [1].

But last few decades have witnessed serious erosion of this breed in India. Primary requirement for genetic improvement of the breed is of larger herd size [2], as larger herd facilitates in more intense selection and gives freedom for voluntary culling to the breeder. Disposal (comprising mortality and culling) of cows is a major constraint in achieving the goal. In India, production traits have been given more emphasis in dairy animals. However, heavy selection pressure on production traits has led a number of problems, especially higher culling and mortality rate in dairy cows $[3,4]$. Knowledge of age/parity specific incidence, pattern of disposal and non-genetic factors associated with disposal of animal is essential, so that appropriate breeding and management strategies could be developed for accelerating the pace of genetic progress for this important milch breed of zebu cattle.

Copyright: The authors. This article is an open access article licensed under the terms of the Creative Commons Attributin License (http:// creative commons.org/licenses/by/2.0) which permits unrestricted use, distribution and reproduction in any medium, provided the work is properly cited.
This review aimed at addressing various components of disposal pattern and various genetic and non-genetic factors influencing them in Sahiwal cattle.

\section{Disposal Pattern}

Disposal pattern covers two traits, i.e., culling and mortality [4,5]. Culling is the removal of cows from the herd because of the sale, slaughter or salvage [6]. Culling is broadly classified into two groups: Voluntary culling and involuntary culling $[7,8]$. Voluntary culling is culling of a cow for low production irrespective of her health, where a healthy cow is replaced because her replacement is more productive [8]. Whereas, involuntary culling is culling of a cow due to disease and/or low fertility or deformity regardless of her performance relative to her herd mates $[8,9]$. High voluntary cull rates would mean that high producing cows would remain in herds for many years. Dairy producers need to focus on the causes of involuntary culling as these are the culls that greatly hamper profitability of a farm [7]. Therefore, high involuntary culling rates are of great concern on dairy farms for both an animal wellbeing and an economic point of view $[4,10]$.

Disposal pattern of cattle has been broadly studied into three groups i.e., abnormal calving, disposal of female calves up to age at first calving (AFC) and disposal of adult lactating cows after entering into the milch herd [11-14]. Abnormal calving has been calculated as percent prenatal calf mortality due to abortion, 
premature birth, and stillbirth $[11,12,14]$, mortality rate up to AFC as percent female calves died out of total live births up to AFC [2], culling rate up to AFC as percent female calves culled out of total live births up to AFC [2], mortality rate at subsequent lactations as percent lactating cows died out of total lactating cows that entered in a given parity in the milking herd [14] and culling rate at subsequent lactations as percent lactating cows culled out of total lactating cows that entered in the given parity in the milking herd [14].

\section{I ncidence of Abnormal Calving and Effect of Non-genetic Factors \\ Incidence}

The literature available on incidence and effect of various non-genetic factors on abnormal calving has been presented in Table-1. The available report on various breeds of cattle indicated that the average incidence of abnormal calving in cows ranged from $3.14 \%$ to $12.0 \%[12,13]$. Among the exotic and crossbred cattle, average incidence was higher in comparison to indigenous cattle, which may be attributed to better adaptability of indigenous cattle than that of exotic and crossbred cattle to Indian tropical climatic conditions. Average incidence of abnormal calving in exotic and crossbred cows was $8.65 \%$, whereas, in Sahiwal cows average incidence was 4.70\% (Table-1).

\section{I nfluence of non-genetic factors}

Significant influence of season of calving on incidence of abnormal calving was reported by some workers [2,11,14-16] (Table-1). Whereas, other workers reported non-significant influence $[12,13,17,18]$. Moreover, winter and summer seasons were reported to be more favorable for normal calvings, whereas, autumn calvers were reported to be more prone to calving abnormalities $[11,14]$. Since, last trimester of gestation plays the most critical role in determining type of calving, therefore, in autumn higher incidence of abnormal calvings could be due to high parasitic load and hot and humid weather conditions in the preceding rainy season encountered during the last trimester of pregnancy.

Regarding the influence of the period of calving most of the workers reported significant effect of period of calving on incidence of abnormal calving [11-18] (Table-1). Whereas, other workers reported non-significant influence of the period of calving on incidence of abnormal calving [2]. An increasing trend of abnormal calving over the periods has been observed in Sahiwal cows at National Dairy Research Institute (NDRI) farm [12,14].

Regarding the influence of parity, some of the workers reported non-significant influence of parity on the incidence of abnormal calving $[2,11,12,18]$ (Table-1). Whereas, other workers reported significant influence of parity order on the incidence of abnormal calving [13,15,16]. Goshu and Singh [13] reported highest incidences of abnormal births in first parity and related it to under developed reproductive system in younger cows by the time of their first calving, resulting in higher incidence of dystocia and prenatal death of calves. Whereas, other workers $[15,16]$ found no definite trend of abnormal calving over the parities, which may be attributed to varying levels of feeding, breeding and management practices adopted at different farms.

\section{Disposal Pattern in Female Calves up to AFC}

Incidence of mortality in various age groups up to AFC in female calves, effect of non-genetic factors and reasons

Incidence

Various studies showed that the average estimate of mortality rate up to AFC in Sahiwal cattle was $24.06 \%$, which ranged from $15.54 \%$ to $35.38 \%[17,18]$. However, the average incidence of mortality up to AFC in exotic and crossbred cattle $(21.89 \%)$ was slightly lower than that of Sahiwal cattle, which ranged from $13.67 \%$ to $45.60 \%$ [11,19]. The average mortality rate among female calves from birth to AFC reported in the literature has been presented in Table- 2 .

If we see the age group wise incidence of mortality (Table-3) than it revealed maximum mortality during the 1st month of age [11,14,20,21]. Moreover, $14 \%$ mortality was reported in $0-1$ month age group of female calves of Sahiwal breed, which was higher in comparison to other age groups [14].

Table-1: Average incidence of abnormal calving (\%) and effect of non-genetic factors.

\begin{tabular}{|c|c|c|c|c|c|c|c|c|}
\hline \multirow[t]{2}{*}{ Breed } & \multirow[t]{2}{*}{ Location } & \multirow[t]{2}{*}{$\mathbf{N}$} & \multirow[t]{2}{*}{ Period } & \multirow[t]{2}{*}{ Average } & \multicolumn{3}{|c|}{ Effects of } & \multirow[t]{2}{*}{ References } \\
\hline & & & & & Season & Period & Parity & \\
\hline KS & Karnal & 1098 & 1966-1991 & 6.40 & $\mathrm{~S}$ & $\mathrm{~S}$ & $\mathrm{~S}$ & [15] \\
\hline KF & Karnal & 3795 & $1964-1994$ & 7.11 & S & $\mathrm{S}$ & $\mathrm{N}$ & [11] \\
\hline $\mathrm{HF}$ & Hisar & 1918 & 1975-1998 & 8.50 & $\mathrm{~S}$ & $\mathrm{~N}$ & $\mathrm{~N}$ & [2] \\
\hline Sahiwal & Karnal & 1116 & $1980-2004$ & 3.14 & $\mathrm{~N}$ & $\mathrm{~S}$ & $\mathrm{~N}$ & [12] \\
\hline Frieswal & Meeruth & 2774 & $1987-2000$ & 11.32 & $\mathrm{~S}$ & $\mathrm{~S}$ & $\mathrm{~S}$ & [16] \\
\hline Sahiwal & Karnal & 946 & $1982-2002$ & 3.17 & $\mathrm{~N}$ & $\mathrm{~S}$ & $\mathrm{~N}$ & [18] \\
\hline Sahiwal & Lakhnow & 2976 & $1968-2002$ & 4.50 & $\mathrm{~N}$ & $\mathrm{~S}$ & - & [17] \\
\hline J ersey $\times$ Sahiwal & Lakhnow & 607 & $1968-2002$ & 6.59 & $\mathrm{~N}$ & $\mathrm{~S}$ & - & [17] \\
\hline Sahiwal & Lakhnow & 752 & 1983-1999 & 7.10 & - & - & - & [24] \\
\hline $\mathrm{HF}$ & Ethiopia & 3092 & $1986-2010$ & 12.00 & $\mathrm{~N}$ & $\mathrm{~S}$ & $\mathrm{~S}$ & [13] \\
\hline Sahiwal & Karnal & 1715 & $1986-2012$ & 5.59 & $\mathrm{~S}$ & $\mathrm{~S}$ & $\mathrm{~N}$ & [14] \\
\hline
\end{tabular}

$\mathrm{N}=$ Non-significant, $\mathrm{S}=$ Significant, $\mathrm{KS}=$ Karan Swiss, KF=Karan Fries, HF=Holstein Friesian 
Available at www.veterinaryworld.org/Vol.7/October-2014/17.pdf

Table-2: Average incidence of overall mortality (\%) up to AFC in female calves and effect of non-genetic factors.

\begin{tabular}{|c|c|c|c|c|c|c|c|c|}
\hline \multirow[t]{2}{*}{ Breed } & \multirow[t]{2}{*}{ Location } & \multirow[t]{2}{*}{$\mathbf{N}$} & \multirow[t]{2}{*}{ Period } & \multirow[t]{2}{*}{ Average } & \multicolumn{3}{|c|}{ Effects of } & \multirow[t]{2}{*}{ References } \\
\hline & & & & & Season & Period/ year & Parity & \\
\hline $\mathrm{KF}$ & Karnal & 3795 & 1964-1994 & 13.67 & $\mathrm{~N}$ & $\mathrm{~S}$ & $\mathrm{~N}$ & [11] \\
\hline $\mathrm{HF}$ & Hisar & 1918 & 1975-1998 & 17.52 & $\mathrm{~N}$ & $\mathrm{~S}$ & $\mathrm{~N}$ & {$[2]$} \\
\hline Sahiwal & Karnal & 1116 & 1980-2004 & 22.63 & $\mathrm{~N}$ & $\mathrm{~S}$ & $\mathrm{~N}$ & [12] \\
\hline Frieswal & Meerut & 2774 & $1987-2000$ & 13.7 & $\mathrm{~S}$ & $\mathrm{~S}$ & $\mathrm{~S}$ & [16] \\
\hline Sahiwal & Karnal & 946 & 1982-2002 & 35.38 & $\mathrm{~N}$ & $\mathrm{~S}$ & $\mathrm{~S}$ & [18] \\
\hline Sahiwal & Lakhnow & 2976 & 1968-2002 & 15.54 & $\mathrm{~N}$ & $\mathrm{~S}$ & - & [17] \\
\hline J Sahiwal & Lakhnow & 607 & $1968-2002$ & 17.83 & $\mathrm{~N}$ & $\mathrm{~S}$ & - & [17] \\
\hline Crossbred & Pantnagar & 1480 & $1994-2002$ & 45.60 & $\mathrm{~S}$ & $\mathrm{~N}$ & - & [19] \\
\hline $\mathrm{HF}$ & Ethiopia & 3092 & $1986-2010$ & 23.00 & $\mathrm{~N}$ & $\mathrm{~S}$ & $\mathrm{~S}$ & [13] \\
\hline Sahiwal & Karnal & 830 & 1986-2009 & 22.70 & - & - & - & [14] \\
\hline
\end{tabular}

$\mathrm{N}=$ Non-significant, $\mathrm{S}=$ Significant, $\mathrm{KF}=$ Karan Fries, $\mathrm{HF}=$ Holstein Friesian, J =J ersey, AFC=Age at first calving

Table-3: Incidence of mortality (\%) in various age groups up to AFC in female calves.

\begin{tabular}{llcccccccc}
\hline Breed & Location & N & Period & 0-1 month & $\mathbf{1 - 3}$ month & $\mathbf{3 - 6}$ month & $\begin{array}{c}\mathbf{6} \text { month } \\
\text { to } \mathbf{1} \text { year }\end{array}$ & $\begin{array}{c}\mathbf{1} \text { year } \\
\text { to AFC }\end{array}$ & $\begin{array}{c}\text { References } \\
\text { KS }\end{array}$ \\
& Karnal & 3168 & $1965-2000$ & 8.55 & 5.33 & 1.51 & 2.05 & 2.58 & {$[20]$} \\
KF & Karnal & 3051 & $1965-2000$ & 4.22 & 5.53 & 1.34 & 1.60 & 2.48 & {$[20]$} \\
KF & Karnal & 1740 & $1964-1994$ & 5.0 & 2.3 & 1.6 & 1.4 & 4.3 & {$[11]$} \\
Gir & - & - & - & 16.92 & 0.00 & 0.00 & 1.85 & - & {$[21]$} \\
HF & Hisar & 413 & $1975-1998$ & 51.7 & & 24.8 & 11.5 & 12 & {$[25]$} \\
KF & Karnal & 1870 & $1992-2009$ & 16.36 & & 2.94 & 4.33 & 2.62 & {$[22]$} \\
Sahiwal & Karnal & 830 & $1986-2009$ & 14.0 & 4.3 & 1.3 & 2.6 & 2.4 & {$[14]$} \\
\hline
\end{tabular}

$\mathrm{KS}=$ Karan Swiss, $\mathrm{KF}=$ Karan Fries, $\mathrm{HF}=$ Holstein Friesian, $\mathrm{AFC}=$ Age at first calving

\section{Influence of non-genetic factors}

Most of the researchers reported non-significant influence of season of birth on mortality in female calves up to AFC [2,11-13,17,18] (Table-2). Whereas, some other workers reported significant influence $[16,19]$. The former reported significantly higher cases of female calf mortality during the summer season $(15.89 \%)$ and rainy season $(18.22 \%)$ than in winter $(11.7 \%)$ and autumn $(8.7 \%)$ in Frieswal cattle. Moreover, Pandey et al. [19] also observed maximum mortality of female calves in summer (52.27\%) and minimum mortality in winter (36.04\%) in crossbreds. The higher mortality in the summer season may be attributed to exposure of calves to adverse hot and humid weather conditions of summer, whereas better care and protection of calves from inclement cold weather conditions would have led to reduced calf mortality in winter season.

Regarding the influence of the period of birth, most of the workers reported significant influence of the period of birth on mortality of female calves up to AFC [2,11-13,16-18] (Table-2). Whereas, Pandey et al. [19] reported non-significant influence of the period on mortality of female calves.

Regarding the influence of parity of dam few researchers reported significant influence of parity of dam on mortality rate up to AFC $[13,16,18]$ (Table-2). Furthermore, it has been reported that incidence of female calf mortality increased among the female calves from older cows beyond fifth parity [18]. Decrease in body nutrient reserves and negative energy balance of cows especially during advanced parities due to greater stress of high milk production would have resulted in weaker female calves born leading to increased female calf mortality.

\section{Reasons of mortality}

In various studies conducted at NDRI, Karnal, it was found that major reasons of mortality in female calves were pneumonia, gastro-enteritis and debility $[14,22]$.

If we correlate the reasons of mortality with the incidence of mortality in various age groups, we could say that higher incidence of mortality were observed in 0-3 month of age group, which could be attributed to higher incidence of pneumonia and gastro-enteritis encountered in this age groups during winter and rainy seasons, respectively. These findings conclude that 0-3 month of age group is most vulnerable to die, therefore, this age group needs special attention to prevent undesirable disposal of female calves prior to entry into a milch herd.

Incidence of culling in various age groups up to AFC in female calves, effect of non-genetic factors and reasons

Incidence

Various studies showed that the estimates of culling rate up to AFC in Sahiwal cattle ranged from $7.10 \%$ to $19.93 \%$ [14,17]. Whereas, in crossbred and exotic cattle breeds, average culling rate ranged from $11.57 \%$ for Frieswal [16] to $31.05 \%$ for HolsteinFriesian [2], with the average being $18.08 \%$. It revealed that the average incidence of culling in female calves was higher in crossbred and exotic breeds of cattle 
in comparison to Sahiwal cattle. The average culling rate among female calves reported in the literature has been presented in Table- 4 .

If we see the age group wise culling rate (Table-5), literature revealed that culling rate was higher in female calves of 1 year of age to AFC in comparison to other age groups.

\section{Influence of non-genetic factors}

Most of the researchers reported that the season of birth did not influence culling rates in female calves [2,11-13,16,17] (Table-4). Significant influence of season on culling rates has been reported by Pandey et al. [19] for crossbreds.

Regarding the influence of the period of birth most of the researchers reported significant influence of the period of birth on culling of female calves $[2,11,13,16,17]$ (Table-4). In the contrary, few workers reported non-significant influence of the period on culling of female calves [12,19].

Regarding the influence of parity of dam most of the workers reported non-significant influence of parity on culling of female calves $[2,11-13,16]$ (Table-4).

\section{Reasons of culling}

In usual practice, female calves are rarely culled to maintain a proper herd size. In a study conducted at NDRI, Karnal, it has been observed that some female calves were culled due to their poor growth and poor reproductive performance, which could be assessed only when the calves have reached to their puberty age [14]. And this may be correlated with comparatively higher incidence of culling reported in sexually mature female calves.

\section{Disposal pattern in adult cows}

Incidence of mortality and culling at various parities in adult lactating cows

The higher incidence of culling has been reported during early lactations and after 420 day post-calving $[4,6]$. Culling rates differ from $<25 \%$ to over 35\%, with $30 \%$ considered average and a culling rate of about $25 \%$ is considered optimal [7]. The literature available on mortality and culling rates at various parities among lactating cows of different breeds and crossbreds has been presented in Tables-6 and 7, respectively.

In various studies conducted at NDRI, Karnal, it has been observed that around $27 \%$ of total cows left the herd in different lactations either due to death or culling. Out of the total loss of $27 \%$ per lactation, the mortality was observed to be around $4 \%$, and culling was found to be around 23\% in Sahiwal cattle [12,14]. Whereas, in another study [11] conducted earlier at same farm in Karan Fries (KF) cattle, total loss per lactation was found to be slightly higher (32.29\%). And of total loss of $32.29 \%$ per lactation, the mortality was observed to be $6.85 \%$ and culling was observed to be $25.43 \%$ [11].

\section{Influence of non-genetic factors}

Scanty literature is available regarding influence of non-genetic factors on incidence of mortality and culling in lactating cows. However, it has been found that period of first calving had highly significant influence on disposal of adult Sahiwal cows up to 4th lactation [14]. Whereas, season of first calving had no influence on disposal up to $4^{\text {th }}$ lactation [14].

Table-4: Average incidence of overall culling (\%) up to AFC in female calves and effect of non-genetic factors.

\begin{tabular}{llccccccc}
\hline Breed & Location & N & Period & Average & & \multicolumn{2}{c}{ Effects of } & References \\
\cline { 6 - 8 } & & & & & & Season & Period/ year & Parity \\
\hline KF & Karnal & 3795 & $1964-1994$ & 23.21 & $\mathrm{~N}$ & $\mathrm{~S}$ & $\mathrm{~N}$ & {$[11]$} \\
HF & Hisar & 1918 & $1975-1998$ & 31.05 & $\mathrm{~N}$ & $\mathrm{~S}$ & $\mathrm{~N}$ & {$[2]$} \\
Sahiwal & Karnal & 1116 & $1980-2004$ & 10.44 & $\mathrm{~N}$ & $\mathrm{~N}$ & $\mathrm{~N}$ & {$[12]$} \\
Frieswal & Meeruth & 2774 & $1987-2000$ & 11.57 & $\mathrm{~N}$ & $\mathrm{~S}$ & $\mathrm{~N}$ & {$[16]$} \\
Sahiwal & Lakhnow & 2976 & $1968-2002$ & 19.93 & $\mathrm{~N}$ & $\mathrm{~S}$ & - & {$[17]$} \\
J×Sahiwal & Lakhnow & 607 & $1968-2002$ & 17.48 & $\mathrm{~N}$ & $\mathrm{~S}$ & - & {$[17]$} \\
Crossbred & Pantnagar & 1480 & $1994-2002$ & 18.18 & $\mathrm{~S}$ & $\mathrm{~N}$ & - & {$[19]$} \\
HF & Ethiopia & 3092 & $1986-2010$ & 7.00 & $\mathrm{~N}$ & $\mathrm{~S}$ & $\mathrm{~N}$ & {$[13]$} \\
Sahiwal & Karnal & 830 & $1986-2009$ & 7.10 & - & - & - & {$[14]$} \\
\hline
\end{tabular}

$\mathrm{N}=$ Non-significani, $\mathrm{S}=$ Significant, $\mathrm{KF}=$ Karan Fries, $\mathrm{HF}=$ Holstein Friesian, J =Jersey, AFC=Age at first calving

Table-5: Average incidence of culling rate (\%) in various age groups up to AFC.

\begin{tabular}{llcccccccc}
\hline Breed & Location & N & Period & 0-1 month & $\mathbf{1 - 3}$ month & 3-6 month & $\begin{array}{c}\mathbf{6} \text { month } \\
\text { to } \mathbf{1} \text { year }\end{array}$ & $\begin{array}{c}\mathbf{1} \text { year } \\
\text { to AFC }\end{array}$ & $\begin{array}{c}\text { References } \\
\text { KS }\end{array}$ \\
& Karnal & 3168 & $1965-2000$ & 0.15 & 0.12 & 1.16 & 2.30 & 14.32 & {$[20]$} \\
KF & Karnal & 3051 & $1965-2000$ & 0.13 & 0.22 & 0.95 & 2.73 & 11.6 & {$[20]$} \\
KF & Karnal & 1740 & $1964-1994$ & 0.5 & 0.4 & 1.7 & 5.0 & 19.4 & {$[11]$} \\
HF & Hisar & 413 & $1975-1998$ & 8.4 & & 4.6 & 20.1 & 67 & {$[25]$} \\
KF & Karnal & 1870 & $1992-2009$ & 0.27 & & 1.23 & 0.80 & 2.95 & {$[22]$} \\
Sahiw-al & Karnal & 830 & $1986-2009$ & 0.10 & 0.00 & 2.10 & 3.20 & 3.70 & {$[14]$} \\
\hline
\end{tabular}

$\mathrm{KS}=$ Karan Swiss, $\mathrm{KF}=$ Karan Fries, $\mathrm{HF}=$ Holstein Friesian, $\mathrm{AFC}=$ Age at first calving 
Available at www.veterinaryworld.org/Vol.7/October-2014/17.pdf

Table-6: Average incidence of mortality (\%) in adult cows during different lactations.

\begin{tabular}{|c|c|c|c|c|c|c|c|c|c|c|c|c|}
\hline \multirow[t]{2}{*}{ Breed } & \multirow[t]{2}{*}{$\mathbf{N}$} & \multicolumn{10}{|c|}{ Lactation } & \multirow[t]{2}{*}{ References } \\
\hline & & 1 & 2 & 3 & 4 & 5 & 6 & 7 & 8 & 9 & 10 & \\
\hline Tharparkar & 1368 & 1.7 & 2.6 & 1.6 & 2.1 & 2.2 & 3.8 & 1.6 & 4.8 & 6.6 & 5.4 & [26] \\
\hline Hariana & 660 & 1.6 & 1.5 & 1.2 & 0.3 & 2.7 & 2.4 & 2.8 & 5.9 & 6.1 & 7.1 & {$[27]$} \\
\hline $\mathrm{KF}$ & 1210 & 3.9 & 6.2 & 7.3 & 6.8 & 11.2 & 9.9 & 10.8 & 12.8 & 15.8 & 27.8 & [11] \\
\hline Sahiwal & 298 & 1.7 & 4.1 & 8.4 & 3.25 & 5.6 & 1.69 & 6.9 & 0.0 & 16.6 & 25 & [12] \\
\hline $\mathrm{HF}$ & 467 & 3.9 & 5.6 & 8.5 & 11.7 & - & - & - & - & - & - & [4] \\
\hline Sahiwal & 473 & 3.6 & 4.4 & 3.5 & 5.5 & 7.5 & 4.7 & 7.1 & 2.7 & 8.0 & 12.0 & [14] \\
\hline
\end{tabular}

$\mathrm{KF}=$ Karan Fries, $\mathrm{HF}=$ Holstein Friesian

Table-7: Average incidence of culling (\%) in adult cows during different lactations.

\begin{tabular}{|c|c|c|c|c|c|c|c|c|c|c|c|c|}
\hline \multirow[t]{2}{*}{ Breed } & \multirow[t]{2}{*}{$\mathbf{N}$} & \multicolumn{10}{|c|}{ Lactation } & \multirow[t]{2}{*}{ References } \\
\hline & & 1 & 2 & 3 & 4 & 5 & 6 & 7 & 8 & 9 & 10 & \\
\hline Tharparkar & 1368 & 20.7 & 24.6 & 24.6 & 19.8 & 22.1 & 22.6 & 23.8 & 29.9 & 32.5 & 32.8 & [26] \\
\hline Hariana & 660 & 19.3 & 22.2 & 14.8 & 12.6 & 12.4 & 13.5 & 16.8 & 25.1 & 28.8 & 31.4 & [27] \\
\hline KF & 1210 & 23.9 & 25.9 & 32.9 & 22.8 & 20.1 & 19.8 & 17.5 & 20.9 & 21.1 & 72.1 & [11] \\
\hline Sahiwal & 298 & 16.4 & 22.9 & 22.4 & 23.5 & 28.8 & 25.4 & 30.2 & 33.3 & 55.5 & 37.5 & [12] \\
\hline $\mathrm{HF}$ & 467 & 16.9 & 23.3 & 30.1 & 40.8 & - & - & - & - & - & - & [4] \\
\hline Sahiwal & 473 & 14.4 & 22.7 & 26.2 & 27.1 & 29.1 & 29.8 & 27.3 & 30.6 & 48.0 & 33.3 & [14] \\
\hline
\end{tabular}

$\mathrm{KF}=$ Karan Fries, $\mathrm{HF}=$ Holstein Friesian

\section{Reasons of disposal}

In exotic cattle major reasons of disposal reported were injury, reproductive problems, mastitis, death and low production as 24.4, 16.2, 14.4, 14.4, and $12.9 \%$, respectively [8]. Whereas, other worker reported that major reasons of disposal in Friesian cows were diseases, death, low production and mastitis as 40.6, 12.2, 7.4, and 3.8\%, respectively [23]. In a study conducted at NDRI, it was found that major reasons of mortality in Sahiwal cows were infectious diseases (33.33\%) and respiratory problems (19.44\%), and other reasons of mortality were hepatic problems, cardio-vascular problems, urinary problems, neuro-musculo-skeletal problems [14]. Whereas major reasons of culling were teat and udder problems (40.82\%), reproductive problems (28.57\%), and low milk production (12.83\%) [14]. Moreover, other reasons contributing to culling were poor health, leg problems, self-sucker etc. [14].

\section{Genetic Analysis of Disposal Pattern}

\section{Abnormal calving}

Effect of sire

Significant effect of sire on abortion has been reported in a study [15], which ranged from 2.94\% to $20 \%$ among the progeny of different sires in Karan Swiss cattle. Highly significant influence of the sire on abnormal calving has also been reported in a study [12]. And the average incidence of abnormal birth was estimated as 3.2\% among 771 pregnancies from 22 sires [12]. Of 22 sires used for breeding, there was no incidence of abnormal births among the pregnancies of 10 sires (45.5\% of total sires). About 54.5\% of total sires used were responsible for abnormal births [12]. Whereas, other researchers reported non-significant influence of the sire on abnormal calving [11]. Later on, highly significant influence of the sire on stillbirth has been reported in another study [19].

\section{Heritability estimates}

The available information regarding the heritability estimates of abnormal calvings indicated very little additive genetic variability in the trait in all the breeds. The heritability estimates of abnormal calving reported in various studies were $0.28,0.101,0.16$, $<0.002$, and 0.056 [11-15], respectively.

\section{Disposal of female calves up to AFC}

Effect of sire on mortality rate of female calves up to AFC

Some workers reported significant influence of the sire on mortality rate of female calves [12,19]. Former one reported no mortality from birth to AFC in female progenies of 2 out of 22 sires. The average mortality was $22.7 \%$, and it ranged from $15.3 \%$ to $48.6 \%$ among the female calves of 20 sires [12]. The mortality was below 20\% among progenies of $36.4 \%$ of the total sires, between $20 \%$ and $30 \%$ among the female calves of $18.2 \%$ sires, 30-40 among the female calves of $22.7 \%$ sires and above $40 \%$ mortality was found among the progeny of $13.6 \%$ sires [12]. On the contrary, other workers reported non-significant influence of the sire on mortality rate of female calves in KF cattle [11].

Effect of sire on culling rate of female calves up to AFC

Some researchers reported non-significant effect of sire on culling rate up to AFC $[11,12]$.

\section{Heritability estimates}

Most of the workers reported very low estimates of heritability of mortality and culling rates of female calves up to AFC [11-13]. The heritability estimates 
for mortality rate were $0.028,0.181$ and 0.180 , respectively, and for culling rate up to AFC were 0.013, 0.065 and 0.710 , respectively, in their studies. The heritability estimates for disposal of the female calves up to AFC was found to be very low (0.025) [14].

\section{Disposal of adult cows}

Scanty literature is available regarding heritability estimates of disposal pattern in adult cows. However, low estimates of heritability of disposal of adult cows up to $4^{\text {th }}$ lactation $(0.120)$ were reported [14]. However, very low estimates of heritability of mortality (0.013) of adult cows have also been reported [3].

\section{Conclusion}

In various studies, major reasons of disposal were found to be mortality in case of female calves and involuntary culling in case of adult lactating cows. Calves during their early months of age (up to 3 month) were more prone to die. Therefore, this age group of calves needs especial attention, especially against adverse weather conditions that would lead to reduced incidence of calf mortality. Most of the adult cows were culled from the herd because of teat and udder and reproductive problems. Hence, it is imperative to lay more emphasis on the measures to minimize teat and udder and reproductive problems, thereby reducing involuntary disposal.

\section{Authors' Contributions}

AU prepared the initial version of the manuscript. SD, MKD, AM, and PRS assisted in literature collection. AU, DKS, AKG, and AKC drafted and revised the manuscript for critical scientific corrections. All authors read and approved the final manuscript.

\section{Acknowledgements}

The authors are indebted to Director, NDRI, Karnal, Haryana, India for providing all possible kind of assistance for the preparation of the manuscript.

\section{Competing I nterests} interests.

The authors declare that they have no competing

\section{References}

1. Mpofu, N. (2002) Choice of genetic types for specific production environments and production systems. AGTR Case Study, ILRI, Nairobi, Kenya.

2. Singh, S., Khanna, A.S. and Singh, R.P. (2002) Replacement and lifetime production traits: Effect of non-genetic factors and sire Evaluation. Asian Australas. J. Anim. Sci., 15: 11-15.

3. Miller, R.H., Kuhn, M.T., Norman, H.D. and Wright, J.R. (2008) Death losses for lactating cows in herds enrolled in dairy herd improvement test plans. J. Dairy Sci., 91: 3710-3715.

4. Pinedo, P.J., De Vries, A. and Webb, D.W. (2010) Dynamics of culling risk with disposal codes reported by Dairy Herd Improvement dairy herds. J. Dairy Sci., 93: 2250-2261.

5. Waldner, C.L., Kennedy, R.I., Rosengren, L. and Clark, E.G. (2009) A field study of culling and mortality in beef cows from western Canada. Can. Vet. J., 50: 491-499.

6. Fetrow, J., Nordlund, K.V. and Norman, H.D. (2006) Invited review: Culling: Nomenclature, definitions, and recommendations. J. Dairy Sci., 89: 1896-1905.

7. Smith, J.W., Ely, L.O. and Chapa, A.M. (2000) Effect of region, herd size, and milk production on reasons cows leave the herd. J. Dairy Sci., 83: 2980-2987.

8. Hadley, G.L., Wolf, C.A. and Harsh, S.B. (2006) Dairy cattle culling patterns, explanations, and implications. J. Anim. Sci., 89: 2286-2296.

9. Rogers, G.W. (2001) Breeding for profitability and Longevity in dairy cattle. All African Dairy Expo, Bloemfontein, Orange Free State, South Africa, p47-49.

10. Weigel, K.A., Palmer, R.W. and Caraviello, D.Z. (2003) Investigation of factors affecting voluntary and involuntary culling in expanding dairy herds in Wisconsin using survival analysis. J. Dairy Sci., 86(4): 1482-1486.

11. Singh, L. (2001) Genetics of replacement rate in Karan Fries cattle. PhD Thesis. NDRI, Karnal, Haryana, India.

12. Abbas, M. (2005) Studies on replacement rate in Sahiwal cattle. MVSc Thesis. NDRI, Karnal, Haryana, India.

13. Goshu, G. and Singh, H. (2013) Genetic and non-genetic parameters of replacement rate component traits in Holstein Friesian cattle. Springer Plus, 2: 581.

14. Upadhyay, A. (2013) Analysis of disposal patterns in Sahiwal cattle. MVSc Thesis. NDRI, Karnal, Haryana, India.

15. Mukherjee, K. and Tomar, S.S. (2000) Genetic and non-genetic factors affecting abnormal births in Karan Swiss cattle. Indian J. Anim. Res., 34: 29-32.

16. Atrey, R.K., Singh, H., Kumar, D. and Sharma, R.K. (2005) Factors affecting the replacement rate and its components in Frieswal cattle. Indian J. Anim. Sci., 75: 324-326.

17. Shahi, B.N. and Kumar, D. (2006) Factors affecting replacement rate and its components in Jersey-Sahiwal cattle. Indian J. Anim. Sci., 76: 855-856.

18. Banik, S. and Naskar, S. (2006) Effect of different non-genetic factors on replacement rate and its components in Sahiwal cattle. Indian J. Anim. Sci., 76: 343-345.

19. Pandey, S., Singh, C.V., Barwal, R.S. and Singh, C.B. (2012) Factors affecting replacement rate and its components in crossbred cattle. Indian J. Dairy Sci., 65: 234-238

20. Saha, S. (2001) Generation wise genetic evaluation of Karan Swiss and Karan Fries cattle. Ph.D. Thesis. NDRI, Karnal, India.

21. Gaur, G.K., Kaushik, S.N. and Garg, R.C. (2003) The Gir cattle breed of India - characteristics and present status. Anim. Genet. Resour. Inf., 33: 21-29. Available from: http:// www.agtr.ilri.cgiar.org/agtrweb/documents/Library/docs/ agri33_03.pdf. Accessed on 10-06-2014.

22. Nehra, M. (2011) Genetic analysis of performance trends in Karan Fries cattle. MVSc Thesis. NDRI, Karnal, Haryana, India.

23. Sadek, M.H., Halawa, A.A., Ashmawy, A.A. and Glil, M.F.A. (2009) Genetic and phenotypic parameter estimation of first lactation, life-time yield and longevity traits in Holstein cattle. Egypt. J. Genet. Cytol., 38: 127-136.

24. Singh, U., Kumar, A., Kumar, S. and Beniwal, B.K. (2011) Evaluation of Sahiwal cattle for lifetime traits in an organized herd. Indian J. Anim. Sci., 81: 708-710.

25. Singh, S., Khanna, A.S. and Jaiswal, U.C. (2006) Demographic analysis of a closed Holstein Friesian herd under tropical climate. Indian J. Anim. Sci., 76: 333-336.

26. Rawal, S.C. and Tomar, S.S. (1998) Population analysis for loss of cows and replacement index in Tharparkar cattle. Indian J. Anim. Sci., 68: 183-184.

27. Kumar, A. (1999) Genetic evaluation of Hariana cattle for selective value. Ph.D. Thesis. CCS, HAU, Hisar, India. 